\title{
Problem of Patient Discrimination in Sphere of Health Protection
}

\author{
Dr. Vitaliy M. Pashkov, PhD Andrii A. Olefir \\ Poltava Law Institute of Yaroslav Mudryi National Law University, Ukraine \\ v.pashkov26.06@ukr.net
}

\begin{abstract}
The article in an investigation of problems of patient discrimination in the sphere of health protection. Grounds for discrimination in this sphere were identified and the most urgent ones detected. Significant attention was paid to the experience of Ukraine in legal regulation of the issue. As for Ukraine, the most problematic matters are discrimination of patients on the basis of sexual orientation and place of residence. In prevention of discrimination an important role is played by international acts. The most important international document, in terms of protecting individual rights, is the European Convention on Human Rights. But international regulations have no specific rules that would prohibit discrimination in the health sector. Such provisions would be reflected in the national legislation. As a result, in the article, there were made practical propositions to the legislation.
\end{abstract}

Keywords: health, patient, medics, human rights, discrimination, sexual orientation.

\section{Introduction}

One of the most important achievements of civilisation is the equality of all people before law, which gives everyone an opportunity to be special, to differ from others and to independently determine their own way of life. But for this, the state must defend a free man, without imposing a particular form of behaviour as the only correct one.

This problem has become significantly topical through the provision of the socalled public services, especially medical care, where a patient may lose their health due to negative subjective attitudes of medics. In practice, there are cases when a doctor, due to low legal culture, has a biased subjective attitude towards a patient. For example, conflict of duty in the provision of health services occurs where a healthcare provider refuses to treat individuals in a certain way because of an objection, based on their own 
religious or other belief, to (a) the treatment for which the patient has been referred to them or which the patient has requested; or (b) the patient as such - for example, because of the sex, sexual orientation or gender identity of the patient [29].

In most cases, human health depends on an individual. But the state policy in the field of public health and quality of organisation of medical services activities is not less important for human health [25].

For a doctor, as well as for a judge, all patients should be equal, with no exception. Doctors are expected to treat all their patients with equal respect, without condemning people who seek help. In turn, each patient has the right to a decent and respectful attitude of medics, not to be discriminated and harassed, and receive appropriate, affordable and equitable medical care. To prevent discrimination, a range of measures should be taken to provide prerequisite for the appropriate regulatory framework. Governments have different approaches of treating the problem of discrimination, sometimes ignoring legitimate interests of certain categories of people. Therefore, international legal acts are an important guarantee of these. As noted by researchers of the rights of mentally ill individuals, provisions of international legal acts aimed at protecting the rights of mentally ill persons play an extremely important role [28].

According to Article 26 of the International Covenant on Civil and Political Rights, all persons are equal before law and are entitled without any discrimination to equal protection of the law. In this respect, the law shall prohibit any discrimination and guarantee to all persons equal and effective protection against discrimination on any ground [18]. Article 2 of the International Covenant on Economic, Social and Cultural Rights addresses this issue in more detail, this issue is regulated more comprehensively: the State's Parties undertake to guarantee that the rights enunciated in the present Covenant will be exercised without discrimination of any kind as to race, colour, sex, language, religion, political or other opinion, national or social origin, property, birth or other status [19].

The most important international document, in terms of protecting individual rights, is the European Convention on Human Rights (hereinafter, ECHR). Article 14 of the Convention has no general prohibition of discrimination, it protects Conventional rights from such offences: the enjoyment of the rights and freedoms set forth in this Convention shall be secured without discrimination on any ground such as sex, race, colour, language, religion, political or other opinion, national or social origin, association with a national minority, property, birth or other status [14].

Thus, an open list of features on the basis of which discrimination is possible can be found in the Convention [14]. The category of "other status" has allowed the ECHR to include those grounds (among others) that are expressly protected by the non-discrimination directives, namely: disability, age and sexual orientation [15].

But Article 1 of Protocol No 12 to the Convention provides a general prohibition of discrimination 1) on any grounds and in respect to 2 ) any law prescribed by national (internal) laws (not only the Conventional rights) [14]. 
The European non-discrimination directives prohibit differential treatment that is based on certain "protected grounds", containing a fixed and limited list of protected grounds, covering sex (Gender Goods and Services Directive, Gender Equality Directive (Recast)), sexual orientation, disability, age or religion or belief (Employment Equality Directive), racial or ethnic origin (Racial Equality Directive) [15].

Prohibition of discrimination is regulated more comprehensively in the Charter of Fundamental Rights of the European Union: Any discrimination based on any ground such as sex, race, colour, ethnic or social origin, genetic features, language, religion or belief, political or any other opinion, membership of a national minority, property, birth, disability, age or sexual orientation shall be prohibited [9].

Thus, international regulations have no specific rules that would prohibit discrimination in the health sector. Such provisions would be reflected in the national legislation. For example, in the UK the Secretary of State's duty as to reducing inequalities reduces a) inequalities between patients with respect to their ability to access health services, and b) inequalities between patients with respect to the outcomes achieved for them by the provision of health services [16].

Before studying of specific manifestations of discrimination in health care, it is worth paying attention to the general theoretical foundations of this issue. The following features of discrimination have to be mentioned:

1) it is a violation of the principle of equality (people are treated not as a person, but as a representative of a group (elderly, women, blacks, "persons of Caucasian nationality", etc.);

2) any personal characteristics (age, sex, language, colour, ethnicity, etc.) can serve as grounds for discrimination;

3) discrimination can be direct and indirect. For example, form of discrimination on the basis of gender: (a) direct discrimination: where, on grounds of sex, one person is treated less favourably than the other is, has been or would be treated in a comparable situation; (b) indirect discrimination: where an apparently neutral provision, criterion or practice would put persons of one sex at a particular disadvantage compared with persons of the other sex, unless that provision, criterion or practice is objectively justified by a legitimate aim and the means of achieving that aim are appropriate and necessary [12].

To confirm the existence of discrimination, the plaintiff is going to prove the following:

1) there were differences in treatment of different persons;

2) as the result of such treatment, one person will obtain a less favourable position than the other, while they are in essentially identical conditions;

3) the only basis for making difference in treatment is one of the discriminatory characteristics (or a combination);

4) there is no objective or reasonable basis for the existence of such differences:

a) achievement of legitimate aim is impossible;

b) there is no reasonable proportionality between measures and goals. 
A legitimate aim may, for example, be protection of victims of sex-related violence (in cases such as establishment of single-sex shelters), reasons of privacy and decency (in cases such as provision of accommodation by a person in a part of that person's home), promotion of gender equality or of interests of men or women (for example, single-sex voluntary bodies), freedom of association (in cases of membership of single-sex private clubs), and organisation of sporting activities (for example, single-sex sports events). Direct discrimination occurs only when one person is treated less favourably, on grounds of sex, than another person in a comparable situation. Accordingly, for example, differences between men and women in provision of healthcare services, which result from physical differences between men and women, do not relate to comparable situations and therefore, do not constitute discrimination [12].

Policy of positive actions is not a discriminative action, it reaches positive goals. It means that the principle of equality shall not prevent the maintenance or adoption of measures providing for specific advantages in favour of the under-represented sex [15, 9]. For example, provision of services without queue for elderly people may not be considered as discrimination against younger people, or state payments for those who decided to change their sex, on sex change operations could not be considered as discrimination against heterosexual women who have decided to increase their breast size. In essence, the policy of positive action is a kind of "compensation" for those individuals who have been or still remain an object for discrimination.

As a rule, scientists offer a limited list of manifestations of discrimination. Specifically, the current study identifies three well-defined types of perceived discrimination that can be associated with poor health outcomes:

1) age discrimination;

2) disability discrimination;

3) sexuality discrimination [1].

Discrimination based on sex, including harassment and sexual harassment, also takes place in areas outside labour market. Such discrimination can be equally damaging, acting as a barrier to full and successful integration of men and women into economic and social life [12].

However, in fact, the list of discrimination grounds is being wider.

\section{Discriminatory Removal Donors from Blood Donation}

According to the legislation of Ukraine, the following forms of risky behaviour serve as absolute contraindications to donation (elimination from donation, regardless of the remoteness of the disease and the results of treatment):

1) provision of sexual services for a fee;

2) sexual relations with strangers without a condom;

3) frequent change of sexual partners; 
4) homosexual relationships;

5) drug addiction [23].

In essence, it is still a Soviet rudiment. But according to the Directive 2004/33/ $\mathrm{EC}$, the following sexual behaviours do not apply to donations: persons whose sexual behaviour puts them at high risk of acquiring severe infectious diseases that can be transmitted by blood [10].

The above-mentioned absolute contraindications to donation in Ukraine are completely wrong, because it is difficult to verify these facts by factual data or due to the frankly discriminatory nature of some of them, such as: provision of sexual services for a fee, frequent changes in sexual partners, homosexual relationships.

In this context, we would like to focus on homosexual relationships as a form of risky behaviour. Such definition, without proper justification, states that all persons with homosexual orientation refer to patients with infectious diseases, which ought to be isolated. There are no particular studies which confirm this.

That is, according to the laws of Ukraine, absolutely all persons who have homosexual orientation are not eligible for donation. Therefore, in order to become blood donors homosexual persons are forced to conceal their real status, which causes their psychological suffering. Thus, the interference in the personal (private) life of homosexual persons is carried out.

Discrimination based on sexual orientation and gender identity is not directly prohibited in Ukraine [37]. Simultaneously, the definition of the notion "discrimination" includes an open list of grounds for discrimination. According to Article 8 of the Convention, there shall be no interference by a public authority with the exercise of this right except such as is in accordance with the law and is necessary in a democratic society in the interests of national security, public safety or the economic well-being of the country, for prevention of disorder or crime, for protection of health or morals, or for protection of the rights and freedoms of others [14]. There are no such grounds in our case.

The ECHR judgment in the case of "Oliari and others vs. Italy" has to be reminded here, in which the court concluded that the restriction on the marriage of a man with a husband or vice versa was not justified both in terms of national security, moral norms, health, and public welfare [4].

In the case of "Geoffrey Leger vs. Minister for Social Affairs, Health and Women's Rights and the French Blood Service", Geoffrey Leger in 2009 appealed to the French Institute of Blood to become a donor. However, he was denied on the grounds that Leger has homosexual orientation that is not in a clear line with the French law. The court found the ban on donating illegal and that it violates Article 14 of the Convention [20].

Besides, the inadmissibility of discrimination on the basis of sexual orientation and gender identity was mentioned in the Resolutions of the Parliamentary Assembly $[30 ; 31]$. 


\section{Discrimination in Insurance Relations}

Some categories of sick people have difficulties in obtaining loans from banks, insurance payments, as insurers are afraid to insure these people. Patients with HIV, disabilities, chronic diseases, pregnant women have such problems. However insurers do not violate the Insurance Law: they have the right to establish different tariffs for different categories of citizens. Without access to medically confidential data, insurers cannot correctly calculate risks and, therefore, provide services for people. People who suffer from incurable diseases are insured "individually" or "with an increasing coefficient". Nevertheless, at the current level of medicine an HIV-infected patient can live as much as a healthy one, and even more - since alcohol and smoking reduce the life expectancy of "healthy people". Thus, the use of age or disability by insurers and banks to assess the risk profile of customers does not necessarily represent discrimination: it depends on the product.

This perspective can be challenged as not recognising the stereotyping which underpins the use of any discrimination ground as a basis for setting different premiums for financial products. A 72-year-old man who is refused travel insurance is suffering from a stereotype that older men are at greater risk of experiencing ill-health. Although this is factually true, it takes no account of the specific health record of an individual customer. The whole point of the law is to require suppliers to treat each person as an individual, not as a member of a group [2].

In this regard, insurance legislation should prohibit the establishment of discriminatory insurance conditions for a particular group of people; therefore, health status should always be assessed on individual basis. It is also necessary to regulate the procedure for insurers' access to electronic medical data.

\section{Discrimination of HIV-infected People and with Excess Weight}

Overweight people often become victims of discrimination in medical institutions. In this case, attitude of doctors to overweight men is more prejudiced than their attitude to women. Medics treat them disrespectfully and consider obesity as a cause of all their illnesses.

Discrimination of HIV-infected people is a bit similar with such problem. AIDS epidemic spreads throughout Europe, but in Ukraine it has acquired the most dangerous features: patients not only hide their status, thereby jeopardising treating physicians (especially dentists), but even patients refuse ARV-therapy and passing of primary tests. The growth of AIDS epidemic is facilitated by the fact that people feel lack of confidence in doctors because of the following circumstances:

1) reduction of staff of specialised medical facilities;

2) absence of real state policy aimed at counteracting HIV infection; 
3) violation of professional and ethical norms among medical staff of public health institutions;

4) disclosure of survey results;

5) lack of effective judicial protection of the rights of patients according to the "system of mutual guarantee" in medicine and absence of independent quality control of medical care.

The next factor is that patients suffer of discrimination. For example, common types of discrimination of HIV-infected people are: firing from a job, refusal to provide proper medical care or pills, lack of adequate psychological support, restriction of the right to education.

\section{Discrimination in Process of Using Auxiliary Reproductive Technologies (Surrogate Motherhood)}

In Germany, attempts to implant embryos in women who intend to abandon their child is a crime. This crime can be committed by a physician responsible for embryo transfer surgery. Surrogacy is also prohibited in the Netherlands, Sweden, Austria and Switzerland. In Spain, only non-commercial surrogate motherhood is allowed. In Canada, surrogate motherhood is not forbidden, but contract with a surrogate mother is not legally valid, that is, a woman (surrogate mother) may keep a born child to herself. The same practice in regulating maternity issues is observed in most European countries where surrogate motherhood is legalised - the mother of the child is considered to be biological mother rather than mother of the genetic.

In Ukraine, surrogate motherhood is allowed; moreover, the liberal order of its implementation is established, as a result of which foreigners come to Ukraine to receive these services.

In Ukraine, according to the order of the Ministry of Health of Ukraine of 09.09.2013 No 787 [22] the mandatory conditions for the use of surrogate maternity is that this service can only be provided for married persons (they give a copy of the marriage certificate).

This provision restricts the rights of single citizens, as well as those who live in civil marriages and homosexual couples. After all, according to Article 21 of the Family Code of Ukraine, marriage is a family union of a woman and a man [33].

Treaty with surrogate mother can be contracted by one of the spouses or both of them; and the genetic connection with the child, carried by a surrogate mother, must be possessed, at least, by one of the spouses [22].

So, there are no objective prerequisites for such restriction of the rights of single citizens, persons living in civil marriages, as well as homosexual couples. That is why we can talk about the presence of signs of discrimination. 


\section{Discrimination by Age (for the Elderly)}

Roots of ageism are gerontophobia and the fear of death, which are deeply embedded in people's minds. Discrimination against the elderly exists in all spheres of life and in patient care as well [32].

This type of discrimination can be held in the following forms:

1) physicians do not consider it necessary to pay a proper attention to diagnostics; in particular, it relates to heavily curable diseases;

2) violation of a patient's right to accurate and complete information (about their health conditions, purpose of the proposed research and medical measures, forecast of possible development of the disease, including existence of a risk to life and health); the provider of services must take into account the difficulty of perceiving information provided by age-related brain work and slow-down reactions;

3) improper service, especially in relation to age-related and seriously curable illnesses (in Ukraine there is a practice of doctors sending elderly people with cancer diseases home 'for dying');

4) insulting and disrespectful, and sometimes superficial attitude of health providers' staff.

Manifestations of such discrimination have not led yet to the formation of significant judicial practice, which is conditioned by the specific behaviour of elderly citizens. They rather take a passive position on protecting of their rights. However, this problem will only intensify over time, if we take into account the age structure of the population of Europe.

Europe is aging and Lithuania is aging twice as fast as Europe on the whole. The main causes are low birth and high emigration rates of younger Lithuanians. At the beginning of 2015 , the population of Lithuania was 2.9 million, including more than 650,000 (or 22.3\%) of pension-aged individuals. The elderly have become a significant part of society, but this does not mean in any way that they have become a privileged part of society. Europe, including Lithuania, has clear legal protection - a convention - for children, but does not have a convention for older persons [32]. Demographic profile of the EU population has seen dramatic changes in recent decades. Most EU Member States have experienced a significant reduction in population growth, which is now primarily fuelled by migration. In 2008 , for example, $1 \%$ of the population increase was due to migrant inflows [17].

In Ukraine, the same causes influenced the demographic crisis. The number of permanent population of Ukraine at the beginning of $2015-42,759,700$ people. The number of persons aged 60 and older is $21.8 \%$ (male $-3,317,300$, female $-6,013,100$ ). The number of children aged 0 to 15 is 6,816,000 people. The share of people in this age group is $15.9 \%$. In Ukraine there is a clear tendency - general aging of the population. According to the international criteria, the population is considered to be old if the share of persons aged 65 and older exceeds $7 \%$. At the beginning of 2015, almost every seventh person in Ukraine was 65 years old or more. The average age of the population of the country at the beginning of 2015 was 40.7 years old [35]. 
Negative statistics also apply to the level of morbidity. According to the World Health Organisation, the global burden of mental illness in 2004 was $13 \%$, and in 2020 it will reach $15 \%$. This indicator is highest for the countries of Eastern Europe, and especially Ukraine [28].

Factors contributing to this:

1) stereotypes in public opinion about the fact that the elderly have poor health and will die soon. This stereotype is denied by the fact that now the achievements of medicine and pharmacy can significantly increase the life expectancy, moreover, older people may have better health than young people who do not lead a healthy lifestyle;

2) stereotype related to the low estimation of the value of life of the elderly.

An important factor is the fact that age discrimination does not fall within the ambit of a particular right in the ECHR (unlike religion, or sexual orientation), issues of age discrimination may arise in the context of various rights. For example, in the case of "Schwizgebel vs. Switzerland", a 47-year-old single mother complained about a refused application to adopt a child. National authorities based their decision on the age difference between the applicant and the child, and the fact that the adoption would impose a significant financial burden, given that the applicant already had one child. The ECHR found that she was treated differently from younger women applying for adoption on the basis of her age. However, lack of uniformity among States over acceptable age limits for adoption allowed the State a large margin of appreciation. Accordingly, the ECHR found that the difference in treatment was justifiable [15].

However, the above-mentioned cases of age discrimination in health care cannot be justified, because there are no reasonable and objective grounds for such distinction.

Such provisions directly prohibit discrimination on the basis of age: Article 21 of the Charter on Fundamental Rights of the European Union [9], Article 6 of the Directive 2000/78/EC establishes justification of differences of treatment on grounds of age, which shall not constitute discrimination, if, within the context of national law, they are objectively and reasonably justified by a legitimate aim, including legitimate employment policy, labour market and vocational training objectives, and if the means of achieving that aim are appropriate and necessary. Such differences of treatment may include, among others:

a) setting of special conditions on access to employment and vocational training, employment and occupation, including dismissal and remuneration conditions, for young people, older workers and persons with caring responsibilities in order to promote their vocational integration or ensure their protection;

b) fixing of minimum conditions of age, professional experience or seniority in service for access to employment or to certain advantages linked to employment;

c) fixing of a maximum age for recruitment which is based on training requirements of the post in question or the need for a reasonable period of employment before retirement [11]. 


\section{Discrimination on Basis of Patient's Welfare}

Medics and healthcare managers often have no interest in providing high-quality services to the so-called free or privileged patients. Those who had received services under the basic insurance policy or within the framework of state programs of free medical care, will suffer such difficulties as: appointment of cheap medicines, use of primitive materials, refusal in sending to a specialised level of services, etc. Instead, patients who pay directly receive a high level of services.

In the United Kingdom, analysis of the 1999 and 2004 England Health Surveys' results depicts a clear relationship between health and socio-economic circumstances across a large number of ethnic groups, including Bangladeshi, Black Caribbean, Chinese, Indian, Irish and Pakistani populations. The findings suggest, however, that while lower socio-economic status plays a significant role in assessing risk of poor health among these groups, health outcomes for poorer persons are often compounded when equality characteristics such as belonging to an ethnic minority are added. This shows that even if migrants arrive in the host country in relatively good health, their health advantage appears to decline over time. Financial barriers emerged as a fundamental and serious obstacle to healthcare for migrants or ethnic minorities. User fees and dental care represent the two most frequently mentioned barriers [17].

Another problem is the inaccessibility of innovative technologies in medicine. Scholars argue that it is necessary to create conditions for patients to access the latest developments and techniques in the medical field without increasing the cost of such treatment through licensing fees [27]. The functioning of healthcare industry in any country is impossible without providing enough medicines for patient care. It obliges the state to improve public health, which must be the highest priority for the government as it relates to the very physical existence of society [26].

In Ukraine, lack of financing is the widespread reason of state's inactivity. For example, persons with the status "Honoured Donor of Ukraine" have the right to free extraordinary prosthetics. But local hospitals often refuse their appeals due to lack of funding. Subsequently, such refusals are challenged in courts and awarded to patients.

The ECHR has developed an approach of resolving such cases: a state, at its own discretion, determines the number of additional budget payments for citizens. A state may enter, suspend or terminate their payment by making appropriate legislative changes. However, if legislative provisions provide certain spending, state authorities will not refuse to grant it until the legislative provision remains in effect. Moreover, the Court does not accept the Government's argument regarding the budget, since public authorities can not refer to lack of funds as a basis for non-fulfilment of obligations [3, 34].

Even during periods of severe resource constraints, the most vulnerable members of society must be protected by adopting relatively low-cost targeted programs. 


\section{Discrimination Based on Sexual Orientation}

Protection against discrimination on the ground of sex has been, and remains, a fundamental function of the European Union. Sexual orientation can be understood to refer to "each person's capacity for profound emotional, affectional and sexual attraction to, and intimate relations with, individuals of a different gender or the same gender or more than one gender". Typically cases relating to sexual orientation discrimination involve an individual receiving unfavourable treatment because they are homosexual or bisexual, but the ground also prohibits discrimination on the basis of being heterosexual [15].

\section{Transsexualism}

The root of problems associated with discrimination on this basis is that transsexuality was not excluded from the International Classification of Diseases. Although in 2011 the European Parliament appealed to the World Health Organisation to eliminate the disorders of sexual identity from the list of mental disorders.

Fortunately, the initiative on this issue has been taken by the ECHR in the case of "P.V. vs. Spain" [5]. The court pointed out that the non-exhaustive list of grounds on which, in accordance with Article 14 of the Convention, discrimination should not be allowed includes transsexualism. Even earlier, a similar conclusion was made with regard to sexual orientation in the case of "Salgueiro Da Silva Mouta vs. Portugal" [7].

Despite the fact that transsexualism is not explicitly indicated as a condition on the basis of which discrimination is prohibited, any forms of discrimination of transsexuals are prohibited.

In Ukraine, there are cases when homosexuals, bisexuals and especially transsexuals find themselves in a desperate situation, without any state support. Being shamed by officials, they make an attempt of suicide. Unfortunately, the state does not undertake any programmes aimed at overcoming the existing discrimination of homosexual, bisexual and transgendered people.

Example of obsolete legislation is the Richards case [8]. Richards, who was born a man, underwent gender reassignment surgery. The case surrounded the State pension entitlement in the UK, as at the time women received their State pension at the age of 60 , while men received their State pension at the age of 65 . When Richards applied for a State pension at the age of 60 , she was refused, with an explanation stating that legally she was recognised as a man and therefore she could not apply for a State pension until she reached the age of 65 . The ECJ held that this was unequal treatment on the grounds of her gender reassignment, and as a consequence this was regarded as discrimination contrary to Article 4 1) of the Directive on the progressive implementation of the principle of equal treatment for men and women in matters of social security $[15,13]$. 
The problem is that surgical operations and other types of medical intervention for people with the diagnosis of "Transsexualism" in all cases are paid by patients themselves. Even more problematic is the financial aspect of surgical operations for sex correction, since a price of such services is much higher than the average monthly income in Ukraine; and the market of such services is not developed. At the same time, in the EU member states, there is a practice of compensating for the costs of treating transsexualism (the hormonal therapy needed for such individuals throughout their lives).

In addition, there are other problems in Ukraine, namely:

1) a person who officially wants to change their sex is forced to carry out a physical operation to change the sex;

2) lack of necessary modern knowledge, qualifications in the field of transsexuality medicine for general practitioners-family doctors.

These ones in Ukraine are authorised to issue medical certificates on the change (correction) of gender identity [24].

\section{Homosexuality}

Despite the fact that homosexuality is excluded from the International Classification of Diseases, in Ukraine the perception of homosexuality as an abnormal behaviour continues. In health care, gender equality implies:

1) equal access of men and women to medical care;

2) equal reception of services in accordance with their real needs;

3) equal quality of medical services.

As already noted, in health care only biological and physiological factors can be considered as fair differences (some diseases are widespread only between men or women, others affect men and women in different ways).

Thus, the ECHR has determined that gender identity, like sexual orientation, forms part of the sphere of an individual's private life, and should, therefore, be free from governmental interference. It should be noted that the ECHR also protects against governmental interference relating to sexual orientation per se under Article 8 of the ECHR on the right to private life. Thus, even if discriminatory treatment based on this ground has occurred, it may be possible simply to claim a violation of Article 8 without needing to argue the existence of discriminatory treatment [15].

In Ukraine, people who have suffered from discrimination must independently prove their claims and objections to the court. Positive assessment should be given to Article 9 of the Directive2004/113/EC, according to which Member States shall take such measures as are necessary, in accordance with their national judicial systems, to ensure that, when persons who consider themselves wronged because the principle of equal treatment has not been applied to them establish, before a court or other competent authority, facts from which it may be presumed that there has been direct or indirect discrimination, it shall be for the respondent to prove that there has been no breach of the principle of equal treatment [12]. 


\section{Discrimination that Depends on Place of Residence}

There are such cases when lack of registration of residence or other identification documents limits the right to health protection. In Ukraine, as a rule, it is impossible to become a donor without registration in a certain region. So, there are many potential donors from the number of students, military, who may not participate in donations.

In such cases employees of blood transfusion stations refer to sub-normative acts, according to which donor's admission to blood transfusion facilities is carried out on the basis of a document certifying the identity and registration. On the other hand, for identification, donor provides personal data that is unique without any risk of misidentification, as well as data for contact with the donor (passport, driver's license, military ticket, identity card, payee identification number) [23].

There is a limitation of personal right to become a donor of blood without proper justification.

More convincing argument is Article 3 of the Law of Ukraine "On freedom of movement and free choice of place of residence in Ukraine", which reads:

\footnotetext{
"Registration of place of residence of a person or its absence may not be a condition for realisation of rights and freedoms, envisaged by the Constitution, laws or international treaties of Ukraine, or grounds for their restriction" [36].
}

If someone has not register his / her place of residence, then in this case, he/she commits an administrative offense for which he / she will be punished [21].

The ECHR in the case of "Pichkur vs. Ukraine", in which the applicant complained that he was deprived of a pension on the basis of his residence, came up with the following conclusions. Firstly, there was recognised violation of Article 14 of the Convention, in conjunction with Article 1 of the First protocol to the Convention. The prohibition of discrimination extends beyond the appliance of rights and freedoms guaranteed by each State as required by the Convention. It also applies to those additional rights that fall within the general scope of any article of the Convention that the States have voluntarily decided to guarantee. Secondly, the difference in treatment is discriminatory if it has no objective and reasonable justification. Each State exercises its discretion in determining how particular differences in other similar situations justify a different attitude [6].

In the case of "Carson and Others $v s$. UK", the applicants complained that the government had discriminated against them on the basis of residence by refusing to allow their pension payments to be revised upwards on the same basis as pensioners residing within the UK or within one of the countries with which the UK has concluded a bilateral agreement in that respect. The ECHR found that although the ECHR creates no right to social security or pension payments, where the State itself decided to do so, this would give rise to a proprietary interest, which would be protected under Article 1 of Protocol 1 [15]. 


\section{Conclusions}

To prevent discrimination on the above-mentioned ground, it is necessary to make the following propositions:

1) provide a new standard of studying for health professionals with an emphasis on inadmissibility of discrimination, the concept of human rights, principles of equality and respect for the rights of people with homosexual and trans-sexual orientation;

2) establish an additional reward for health professionals who participate in treating of special patient groups, in particular elderly people, people with homosexual and trans-sexual orientation;

3) ensure a patient's confidence in the fact that "response" actions of medical institution will not be undertaken, if one had passed a complaint against discrimination of medical staff or another violations in relation to this patient. Therefore, in medical institutions questionnaires should be provided for all patients, in which they can answer particular questions (facts of discrimination, violation of patient's rights, etc.);

4) provide compulsory HIV-testing for primary and periodic medical examinations;

5) create special units, in the structure of the Ministry and local health bodies, whose sole function is to counteract all forms of discrimination in the sphere of health care, as well as elaboration of proposals for legislation;

6) adopt national laws (international legal acts) that provide protection of the rights of elderly citizens;

7) establish a new (special) form of liability with strict sanctions for discriminatory behaviour of medics;

8) adopt special legislation that clearly prohibits all forms and grounds for discrimination in health sector, namely: any discrimination based on race, colour, sex, language, religion, political or other opinion, national or social origin, property, income, birth, age, physical or mental disability, including overweight, health (including HIV / AIDS), sexual orientation and gender identity, civil, political, social ceiling elements with regard to access to basic health care services. 
Vitaliy M. Pashkov, Andrii A. Olefir. Problem of Patient

Discrimination in Sphere of Health Protection

\section{Pacienta diskriminācijas problēmas veselības aizsardzības jomā}

\section{Kopsavilkums}

Šajā rakstā autori analizē pacienta diskriminācijas problēmas veselības aizsardzības jomā. Tiek identificēti diskriminācijas iemesli šajā jomā, akcentējot visaktuālākos. Būtiska uzmanība tiek pievērsta Ukrainas pieredzei šĩ jautājuma tiesiskajā regulējumā. Saistībā ar tiesisko regulējumu Ukrainā aktuāli ir jautājumi par pacientu diskrimināciju, pamatojoties uz seksuālo orientāciju un dzīvesvietu. Diskriminācijas novēršanā svarīga nozīme ir starptautiskajiem aktiem. Vissvarīgākais starptautiskais dokuments attiecībā uz indivīdu tiesību aizsardzību ir Eiropas Cilvēktiesību konvencija. Savukārt starptautiskajā tiesiskajā regulējumā nav īpašu noteikumu, kas aizliedz diskrimināciju veselības jomā. Šādiem noteikumiem vajadzētu būt atspoguḷotiem nacionālajos tiesību aktos. Raksta noslēgumā tika izdarīti praktiski piemērojami priekšlikumi grozījumiem tiesību aktos.

Atslēgvārdi: veselība, pacients, mediḳi, cilvēktiesības, diskriminācija, seksuālā orientācija.

\section{References}

1. Alvarez-Galvez, J., Salvador-Carulla, L. Perceived Discrimination and Self-Rated Health in Europe: Evidence from the European Social Survey. PLOS ONE, September 5, 2013. Available from http://journals.plos.org/plosone/s/contact [reviewed 07.02.2018].

2. Bell, M. Advancing EU Anti-Discrimination Law: the European Commission's 2008 Proposal for a New Directive. The Equal Rights Review, 2009, 3, 7-18. Available from http://www.equalrightstrust.org/ertdocumentbank/mark\%20bell.pdf [reviewed 07.02.2018].

3. Case of Burdov vs. Russia (Application No. 59498/00). European Court of Human Rights: Judgment, 7 May 2002. Available from http://sutyajnik.ru/rus/echr/judgments/burdov.htm [reviewed 07.02.2018].

4. Case of Oliari and Others vs. Italy: a stepping stone towards full legal recognition of samesex relationships in Europe. Strasbourg Observers. Available from https://strasbourgobservers. com/2015/09/16/oliari-and-others-v-italy-a-stepping-stone-towards-full-legal-recognitionof-same-sex-relationships-in-europe/ [reviewed 07.02.2018].

5. Case of P. V. vs. Spain (Application No. 35159/09). European Court of Human Rights: Judgment, 30 November 2010. Available from https://genderidentitywatch.files.wordpress.com/2013/12/ chamber-judgment-p-v-v-spain-30-11-2010.pdf [reviewed 07.02.2018].

6. Case of Pichkur vs. Ukraine (Application no. 10441/06). European Court of Human Rights: Judgment, 7 November 2013. Available from https://www.ochrance.cz/fileadmin/user_upload/ DISKRIMINACE/aktuality/CASE_OF_PICHKUR_v._UKRAINE.pdf [reviewed 07.02.2018].

7. Case of Salgueiro Da Silva Mouta vs. Portugal (Application No. 33290/96). European Court of Human Rights: Judgment, 21 December 1999. Available from http://www.equalrightstrust.org/ ertdocumentbank/Microsoft\%20Word\%20-\%20Salgueiro\%20Da\%20Silva\%20Mouta\%20v\%20 Portugal\%20_parental\%20responsibility_.pdf [reviewed 07.02.2018]. 
Vitaliy M. Pashkov, Andrii A. Olefir. Problem of Patient

Discrimination in Sphere of Health Protection

8. Case of Sarah Margaret Richards vs. Secretary of State for Work and Pensions (Case C-423/04). European Court of Justice, 27 April 2006. Available from http://eur-lex.europa.eu/legal-content/ EN/TXT/PDF/?uri=CELEX:62004CJ0423\&from=EN [reviewed 07.02.2018].

9. Charter on Fundamental Rights of the European Union (2000/C 364/01). Official Journal of the European Communities, 18.12.2000. Available from http://www.europarl.europa.eu/charter/pdf/ text_en.pdf [reviewed 07.02.2018].

10. Commission Directive 2004/33/EC of 22 March 2004 implementing Directive 2002/98/EC of the European Parliament and of the Council as regards certain technical requirements for blood and blood components. Official Journal of the European Union, 30.3.2004. Available from http:// eur-lex.europa.eu/LexUriServ/LexUriServ.do?uri=OJ:L:2004:091:0025:0039:EN:PDF [reviewed 07.02.2018].

11. Council Directive 2000/78/EC of 27 November 2000 establishing a general framework for equal treatment in employment and occupation. Available from http://eur-lex.europa.eu/legal-content/ en/TXT/?uri=CELEX\%3A32000L0078 [reviewed 07.02.2018].

12. Council Directive 2004/113/EC of 13 December 2004 implementing the principle of equal treatment between men and women in the access to and supply of goods and services. Official Journal of the European Union, 21.12.2004. Available from http://eur-lex.europa.eu/LexUriServ/ LexUriServ.do?uri=OJ:L:2004:373:0037:0043:en:PDF [reviewed 07.02.2018].

13. Council Directive 79/7/EEC of 19 December 1978 on the progressive implementation of the principle of equal treatment for men and women in matters of social security. Available from http:// eur-lex.europa.eu/legal-content/EN/TXT/PDF/?uri=CELEX:31979L0007\&from=EN [reviewed 07.02.2018].

14. European Convention on Human Rights: Convention for the Protection of Human Rights and Fundamental Freedoms, 4.11.1950. Available from http://www.echr.coe.int/Documents/ Convention_ENG.pdf [reviewed 07.02.2018].

15. Handbook on European non-discrimination law. European Union Agency for Fundamental Rights, 2010. Online available from http://fra.europa.eu/sites/default/files/fra_uploads/1510FRA-CASE-LAW-HANDBOOK_EN.pdf [reviewed 07.02.2018].

16. Health and Social Care Act 2012. Legislation.gov.uk. Available from http://www.legislation.gov. uk/ukpga/2012/7/contents/enacted [reviewed 07.02.2018].

17. Inequalities and multiple discrimination in access to and quality of healthcare. European Union Agency for Fundamental Rights, March 2013. Available from http://fra.europa.eu/en/publication/2013/inequalities-discrimination-healthcare [reviewed 07.02.2018].

18. International Covenant on Civil and Political Rights. Adopted by the General Assembly of the United Nations on 19 December 1966. Available from https://treaties.un.org/doc/publication/ unts/volume\%20999/volume-999-i-14668-english.pdf [reviewed 07.02.2018].

19. International Covenant on Economic, Social and Cultural Rights. Adopted by the General Assembly of the United Nations on 16 December 1966. Available from https://treaties.un.org/ doc/Treaties/1976/01/19760103\%2009-57\%20PM/Ch_IV_03.pdf [reviewed 07.02.2018].

20. Judgment of the Court (Fourth Chamber) of 29 April 2015 (request for a preliminary ruling from the Tribunal administrative, Strasbourg - France) - Geoffrey Léger vs. Ministre des Affaires sociales, de la Santé et des Droits des femmes, Établissement français du sang (Case C-528/13) Available from http://eur-lex.europa.eu/legal-content/en/TXT/PDF/?uri=uriserv\%3 AOJ.C_.2015.213.01.0007.01.ENG [reviewed 07.02.2018]. 
21. Kodeks Ukrayiny pro administratyvni pravoporushennya vid 7 grudnya 1984 roku № 8073-X (Eng. Code of Ukraine on Administrative Offenses of 7 December 1984 No 8073-X). Available from http://zakon2.rada.gov.ua/laws/show/80731-10/print [reviewed 07.02.2018].

22. Nakaz Ministerstva oxorony zdorovya Ukrayiny "Pro zatverdzhennya Poryadku zastosuvannya dopomizhnyx reproduktyvnyx texnologij vs. Ukrayini” vid 09.09.2013 roku № 787 (Eng. Order of the Ministry of Health of Ukraine "On Approval of the Procedure for the Application of Assisted Reproductive Technologies in Ukraine” of 9 September 2013 No 787). Available from http://zakon3. rada.gov.ua/laws/show/z1697-13 [reviewed 07.02.2018].

23. Nakaz Ministerstva oxorony zdorovya Ukrayiny 01.08.2005 roku No 385 (Eng. Order of the Ministry of Health of Ukraine of 1 August 2005 No 385). Available from http://zakon3.rada.gov. ua/laws/show/z0896-05 [reviewed 07.02.2018].

24. Nakaz Ministerstva oxorony zdorovya Ukrayiny vid 05.10.2016 roku № 1041 (Eng. Order of the Ministry of Health of Ukraine of 05.10.2016 No 1041). Available from http://zakon0.rada.gov.ua/ laws/show/z1589-16 [reviewed 07.02.2018].

25. Pashkov, V., Batyhina, O., Trotska, M. Legal restraints of pesticide effect on human organism and environment under international legislation. Wiadomości Lekarskie. 2017, 2, 366-372.

26. Pashkov, V., Golovanova, I., Olefir, A. The impact of the legal regime of intellectual property protection in the pharmaceutical market. Wiadomości Lekarskie. 2016, 3, 582-587.

27. Pashkov, V., Hrekov, Y., Hrekova, M. The directions of development of legal regulation of patenting the methods of treatment in Ukraine considering the European and world experience. Wiadomości Lekarskie. 2017, 3, 628-633.

28. Pashkov, V., Olefir, A. Problems of Rehabilitation of Mentally Ill Persons: the International Legal Aspect (Ukrainian Experience). Acta Balneologica, 2017, T. LIX, 4(150), 341-353.

29. Petrova, D., Clifford, J. Religion and Healthcare in the European Union Policy issues and trends. NEF Initiative on Religion and Democracy in Europe, 2009. Available from http://nefnew.org/ wp-content/uploads/2013/03/NEF-RelDem-RELIGION-HEALTHCARE-Final.pdf [reviewed 07.02.2018].

30. Resolution 1728 (2010) "Discrimination on the basis of sexual orientation and gender identity". Parliamentary Assembly. Online available from http://assembly.coe.int/nw/xml/XRef/XrefXML2HTML-EN.asp?fileid=17853\&lang=en [reviewed 07.02.2018].

31. Resolution 1948 (2013) "Tackling discrimination on the grounds of sexual orientation and gender identity”. Parliamentary Assembly. Available from http://assembly.coe.int/nw/xml/XRef/XrefXML2HTML-en.asp?fileid=20010\&lang=en [reviewed 07.02.2018].

32. Selli, K., Czabanowska, K., Danusevičienė, L., Butkevičienė, R., Jurkuvienė, R., Overall, J. Discrimination of elderly patients in the health care system of Lithuania. South Eastern European Journal of Public Health, 2016, 6. Available from http://www.seejph.com/index.php/seejph/ article/view/124 [reviewed 07.02.2018].

33. Simejnyj kodeks Ukrayiny vid 10 sichnya 2002 roku № 2947-III (Eng. Family Code of Ukraine of 10 January 2002 No 2947-III). Available from http://zakon3.rada.gov.ua/laws/show/2947-14 [reviewed 07.02.2018].

34. Sprava "Suk proty Ukrayiny” (Zayava № 10972/05). Rishennya Yevropejskogo sudu z prav lyudyny vid 10 bereznya 2011 roku (Eng. Case "Suk against Ukraine” (Statement No 10972/05). European Court of Human Rights: Judgment of 10 March 2011). Available from http://zakon2.rada.gov.ua/ laws/show/974_715 [reviewed 07.02.2018]. 
35. Zagalna xarakterystyka statevo-vikovogo skladu naselennya Ukrayiny na 1 sichnya 2015 roku (Eng. General characteristics of the sex-age composition of the population of Ukraine on January 1 2015). Available from http://database.ukrcensus.gov.ua/PXWEB2007/ukr/publ_new1/2015/ dem_zag_0115.pdf [reviewed 07.02.2018].

36. Zakon Ukrayiny "Pro svobodu peresuvannya ta vilnyj vybir miscya prozhyvannya v Ukrayini" vid 11.12.2003 r. № 1382-IV (Eng. Law of Ukraine "On Freedom of Movement and Free Choice of Place of Residence in Ukraine” of 11 December 2003 No 1382-IV). Available from http://zakon2. rada.gov.ua/laws/show/1382-15 [reviewed 07.02.2018].

37. Zakon Ukrayiny "Pro zasady zapobigannya ta protydiyi dyskry'minaciyi v Ukrayini” vid 6 veresnya 2012 roku № 5207-VI (Eng. The Law of Ukraine "On the Principles of Prevention and Counteraction of Discrimination in Ukraine” of 6 September 2012 No 5207-VI). Available from http://zakon3.rada.gov.ua/laws/show/5207-17 [reviewed 07.02.2018]. 